\title{
RENDIMENTO DE MILHO EM ÁREA DE INTEGRAÇÃO LAVOURA-PECUÁRIA SOB O SISTEMA DE PLANTIO DIRETO, EM PRESENÇA E AUSÊNCIA DE TREVO BRANCO, PASTEJO E NITROGÊNIO
}

\section{YIELD OF CORN IN AREA OF CROP X PASTURE INTEGRATION UNDER THE SYSTEM OF NO TILLAGE, IN PRESENCE AND ABSENCE OF WHITE CLOVER, GRAZING AND NITROGEN}

\author{
Tangriani Simioni ASSMANN \\ Orientador(a): Prof. Dr. Pedro RONZELLI JÚNIOR \\ (Departamento de Fitotecnia e Fitossanitarismo)
}

\begin{abstract}
RESUMO
O trabalho experimental foi conduzido no campo, na Estação Experimental da Fundação Agrária de Pesquisa Agropecuária (FAPA), nos anos agrícolas de 1999 e 2000, com o objetivo de verificar a influência da adubação nitrogenada residual para a cultura do milho, em sistema de plantio direto, em presença e ausência tanto de trevo branco quanto de animais em pastejo. O delineamento experimental foi o de blocos ao acaso com três repetições. Os tratamentos foram arranjados em parcelas subdivididas. No inverno, nas parcelas, foram colocados quatro níveis de nitrogênio $\left(\mathrm{N}-\mathrm{TI}=0,100,200\right.$ e $\left.300 \mathrm{~kg} \cdot \mathrm{ha}^{-1} \mathrm{de} \mathrm{N}\right)$ e, nas subparcelas, a combinação de presença e ausência de trevo branco e de pastejo (CT = com trevo; $\mathrm{ST}=$ sem trevo; $\mathrm{CP}=$ com pastejo e $\mathrm{SP}=$ sem pastejo). No verão, em cada subparcela proveniente do inverno, foram colocadas cinco doses de $\mathrm{N}$, em cobertura, (N-TV = 0,60, 120, 180 e $240 \mathrm{~kg}^{-\mathrm{ha}^{-1}} \mathrm{de}$ $\mathrm{N})$ e cultivado o milho. Dezoito dias após a retirada dos animais a máxima eficiência técnica de rebrote da cultura de inverno foi obtida com $231 \mathrm{~kg} \cdot \mathrm{ha}^{-1} \mathrm{de} \mathrm{N}(\mathrm{N}-\mathrm{TI})$. As áreas CP/N-TI mostraram tendência de apresentar maiores produtividades do milho que as áreas SP. As áreas sem N-TI produziram mais milho em subparcelas SP. As parcelas que receberam $300 \mathrm{~kg}^{-\mathrm{ha}^{-1}} \mathrm{de} \mathrm{N} \mathrm{N-TI} \mathrm{não} \mathrm{mostraram}$ resposta do milho ao N-TV, comprovando o efeito residual do N-TI. Conclui-se que a interação entre pastejo e N-TI contribui para a nutrição nitrogenada da cultura do milho.

Palavras-chave: milho, Zea mays, integração lavoura-pecuária, nitrogênio.
\end{abstract}

\begin{abstract}
A field experiment was carried out, during the 1999 and 2000 growing season, at the Fundação Agrária de Pesquisa Agropecuária [Agrarian Foundation for Agricultural and Cattle Research] (FAPA), in Guarapuava, state of Paraná, Brazil, with the objective to verify the influence of the residual nitrogen fertilization on maize crop, on no tillage system, in presence and absence of white clover and grazing. The experimental design was the complete randomized blocks with tree replications. The treatments were arranged in split-plot model. During the previous Winter season four N levels $\left(\mathrm{N}-\mathrm{TI}=0,100,200\right.$ e $\left.300 \mathrm{~kg}^{-h^{-1}} \mathrm{de} \mathrm{N}\right)$, were applied to the main plots, and the combination of presence and absence of white clover and grazing (CT = clover presence; $\mathrm{ST}=$ clover absence; $\mathrm{CP}=$ grazing presence, and SP = grazing absence), to the sub-plots. At the Summer season in each sub-plot prepared during the previous Winter season five $\mathrm{N}$ cover levels $\left(\mathrm{N}-\mathrm{TV}=0,60,120,180 \mathrm{e} 240 \mathrm{~kg}^{-h^{-1}} \mathrm{de}^{\mathrm{N}}\right)$, were applied and corn cultivated. Eighteen days after the animals were

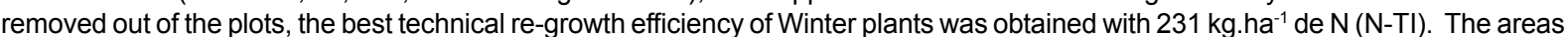
$\mathrm{CP} / \mathrm{N}-\mathrm{TI}$ showed tendency to present better corn production. The areas without $\mathrm{N}-\mathrm{TI}$ yielded more in the SP subplots. The plots that received $300 \mathrm{~kg} \cdot$ ha $^{-1}$ de N N-TV did not show corn response to the N-TV, confirming the residual effect of N-TI. The conclusion is that the interaction between grazing and $\mathrm{N}-\mathrm{TI}$ contributes to the maize nitrogen.

Key-words: corn, Zea mays, crop-pasture rotation, nitrogen.
\end{abstract}

